Extended Abstract

\title{
Is the civic attitude of e-participation really wise in the current information society?
}

\author{
Marcelo León ${ }^{1, *}$, Enrique Diez ${ }^{2}$ \\ ${ }^{1}$ Marcelo León Castro / León - España (marceloleon11@hotmail.com) \\ ²Enrique Díez Gutiérrez / León - España (ejdieg@unileon.es) \\ * Tel.: +34 674992011
}

Accepted:

\section{Introduction (M_Heading1)}

In recent years the speeches about the democratizing potential of the Internet and social networks have been proliferating. The theoretical spectrum of all these speeches ranges from consideration of the Internet and social networks as complement of the procedures and techniques used by representative democracy (as "digital democracy") up to their potential to generate new forms of citizenship in the way towards new direct democracy. The analysis which takes place here explores to what extent the Internet and social networks are changing the relations and attitudes civic between governments and citizenship, even if, indeed, represent another form of constructing citizenship and democratic political participation through social mobilization, moving towards strong and direct sense of democracy and even the possibility of arriving at self-participatory government.

Or, rather, we are faced with a certain idealization of the great potential of the Internet and social networking, where mythical speeches that anticipate the desirable uses of these tools in the field of social and political participation arise. Perhaps, we just deal with a digital activism, obsessed by the clicks made on the Internet and social networks in favour of a cause, that you are introducing high doses of trivialization practice of civic commitment, delimited and domesticated commercially by the owners of this virtual cyberspace who control the possibilities and the limits of a captive "pseudocitizenship" in the kingdom of the cyberspace. In short, we can say that the Internet and social networks can lead to boom or to doom: they can lead to the materialization of the technological utopias of a more egalitarian world or, conversely, can reproduce and further exacerbate the imbalances of power that already exists in the social reality. This is the challenge, this is the defiance. The future is being built with the networks we are creating. 
Methods (M_Heading1)

\section{Results and Discussion (M_Heading1)}

The Internet: Participation or trivialization of civic engagement?. -Here we will contemplate to what extent the Internet and social networks are changing the relationship between government and citizenship - whether they represent another way of building citizenship and democratic political participation through social mobilization, advancing towards strong, direct democracy and even the possibility of participatory self-government or if we rather have a certain idealization on the great potential of the Internet and social networks, where civic engagement is bounded and domesticated commercially by the owners of this virtual cyberspace that are those who control the possibilities and limits of a "pseudociudadania" captive in the realm of cyberspace(Hurtado y Naranjo, 2002).

Democracy digital 4.0.- One of these is Democracy 4.0. (2012), supported by Democracy Real Ya (DRY) initiative. This initiative proposes that citizens participate from home directly via the Internet in making decisions that affect them. The truth is that the participation in social networks is changing the landscape of the democratic practices from the role of political parties and their usage of the networks during their campaigns and in the subsequent political work up to the pressure through networks (e.g. the case of wikileaks) in favour of greater transparency of governments, banks and major multinationals and their practices.

The participation on the Internet: beyond the Slack-clickactivismo.-the "brecha digital” not only of access to web 1.0 (access to the Internet - seniors, rural areas, countries of the South, etc.), but Web 2.0 (which produces content and relationships in cyberspace) requires us to ask ourselves if really the access to the network is democratized, and whether the content production has become democratized. "Clickactivismo" is digital activism that tends to embrace the ideology of marketing without too much criticism. Obsessed by the pursuit of the clicks made on the Internet for a cause or an ONG, accepts implicitly that the advertising and market research tactics used for selling toilet paper can also build citizenship. This practice shows an excessive faith in the power of metrics to measure success, 'typical' style of social networks that count the number of "friends" they possess.

The Internet and the Arab spring - It is possible in this context that collective action can flourish in the network. In case of flourishing, we must ask ourselves if it has been a "digital revolution". Let's analyze the example of the so-called "Arab spring". It is true that what happened in Egypt in February of 2011 and ended in the overthrow of Hosni Mubarak seems to point at the Internet and social networks, Facebook and Twitter, as well as the messages via mobile phones according to the information presented in the media. "A revolution of social networks, which makes it possible to advance democracy", it was said by many people who seem to consider the social networking sites as the new weapons that are possessed by the citizens in the streets to confront the power today. These are the cellular text messages (or the messages on Twitter and Facebook) spread by libertarians that transmit relevant information that the media serving the power normally hides". 
The utopia of democratic citizenship cybernetics.- One might, therefore, wonder if, despite all its limitations, the appearance of this type of virtual social spaces would decrease the interest in the social and political involvement of youth in Spain. Time will tell if the Internet and social networks will be converted into a tool for empowerment of groups, communities and social movements. If with their help the globalization of the environment and human rights is going to be possible in order to mobilize action, exert pressure, install issues and legitimize dissident voices in national and international agendas, it would be as effective as the globalization of capitalism has been as well as the one of the financial institutions and multinational companies that manage the economy and world politics using the new technologies.

Civic socialization in the social networks.- The concept of citizenship responds to contemporary social responsibility in action (Hobsbawm, 1998), which is exercised by the right to effective decision-making participation in the social, economic and political areas (García Canclini, 1995). We advocate the concept of participatory citizenship suggested by Suarez (2005) who founded the social membership and associated rights which are not so much a formal citizenship - and in many times passive - as in active involvement in the community where he lives. This approach questions the liberal model of citizenship, pointing at the necessary extension of citizenship to a true model of post-national and post-colonial citizenship (Suarez, Macia and Moreno, 2007) moving towards the forms of participatory democracy.

\section{Conclusions (M_Heading1)}

In the final analysis, we can say that the Internet and social networks can lead to the boom or to the doom: on the one hand they can lead to the materialization of technological utopias of a more egalitarian world, on the other hand they can reproduce and further exacerbate the imbalance of power that already exists in the social reality. Networks can be used to entangle (for the construction of networks aimed at social change) or to clutter (for social fragmentation and the dispersion in respect of the strategies for change) (Mari, 2007). New possibilities for participation, access to multiple information sources and the horizontal model of communication generate the space for social interaction that goes beyond the classical cartography and the bodily limits, making it possible to overcome certain physical, social and even psychological and political barriers.

\section{Acknowledgments}

\section{References and Notes}

1. Caldevilla Domínguez, D. (2010). Las Redes Sociales. Tipología, uso y consumo de las redes 2.0 en la sociedad digital actual. Documentación de las Ciencias de la Información, 33, 45-68.

2. Castells, M. (2009). Comunicación y poder. Madrid: Alianza Editorial.

3. Chomsky, N. (2010). Las 10 principales estrategias de manipulación mediática. [Recuperado el 13 de febrero de 2011 de http://www.cubadebate.cu/opinion/2010/09/15/noam-chomsky-y-las-10-estrategiasde-manipulacion-mediatica/] 
4. De Moraes, D. (2004). El activismo en Internet: nuevos espacios de lucha social. [Recuperado el 13 de febrero de 2011 de http://www.rebelion.org/hemeroteca/cibercensura/040202.htm]

5. Del Moral, J.A. (2005). Redes Sociales ¿Moda o nuevo paradigma? Madrid: Asociación de usuarios de Internet.

6. Democracia 4.0. (2012). Democracia Real Ya llama a la ciudadanía a sumarse a la petición de una Democracia 4.0 para ejercer su soberanía [Recuperado el 13 de noviembre de 2012 de http://demo4punto0.net/it/node/15]

7. DíazNafría, J.M., Alfonso Cendón, J., Panizo Alonzo, L. Building up eParticipatorydecisión-making from the local to the global scale. Study case at theEuropeanHigherEducationArea.

8. DíazNafría, J.M. (2015). Ethics at the age of information. System (2015) in press.

9. Díez Rodríguez, A. (2003). Ciudadanía cibernética. La nueva utopía tecnológica de la democracia. En J. Benedicto y M. L. Morán (ed.) Aprendiendo a ser ciudadanos (193-218). Madrid: Injuve.

10. Hurtado Galeano, D. y Naranjo Giraldo, G. (2002). Aprendizajes sociales y pedagogías ciudadanas. Apuntes para repensar la formación de ciudadanía en Colombia. Estudios Políticos, 21, 145-159.

11. Levy, P. (1997). La cibercultura, el segondiluvi? Barcelona: EdiUOC-Proa.

12. Marí, V. M. (2010). Tecnologías de la Información y Gobernanza Digital. Los usos ciudadanos de Internet en el espacio local de Jerez de la Frontera. Historia Actual Online, 21, 173-187.

13. Marí, V. M. (2007). Contra la evaporación de la dimensión política de la comunicación. Movimientos sociales, ONG y usos de Internet. ZER, 22, 453-471.

14. Monbiot, G. (2011). Online astroturfing is more advanced and more automated than we'd imagined. The Guardian, 23 Febrero [http://www.monbiot.com/2011/02/23/robot-wars/ Recuperado el 19 de marzo de 2011].

15. Navarro, V. (2011). Lo que no se conoce sobre Egipto. Público, 17 febrero 2011. [Recuperado el 19 de marzo de 2011 de http://blogs.publico.es/dominiopublico/3047/lo-que-no-se-conoce-sobre-egipto/].

16. Putnam, R. (2009). The myth of digital democracy. New Jersey: Princenton University Press.

17. Van Alstyne, M. y Brynjolfsson, E. (1996). Electronic Communities: Global Village or Cyberbalkans? En J. DeGross, S. Jarvenpaa, y A. Srinivasan (Eds.), Proceedings of the 17th International Conference on Information Systems.New York: Wiley.

(C) 2015 by the authors; licensee MDPI and ISIS. This abstract is distributed under the terms and conditions of the Creative Commons Attribution license. 